\title{
207 北九州地域の耐火棟瓦とその製造小史
}

\section{Firebricks for industrial use remain in Kitakyushu district and their short history}

\author{
○ 青地 学（ポリテク八幡） 正 堤 一郎（職業大）
}

AOCHI Manabu, Yahata Polytechnic Centre, 3-5-1 Anou,Yahatanishi,kitakyushu-shi,Fukuoka TSUTSUMI Ichiro, Polytechnic University of Japan

\begin{abstract}
In this report, Firebricks for industrial use remain in Kitakyushu district and their short history will be explained. Contents of this report are as follows.

1) A short history of foundations of firebrick manufacturer in Kitakyushu district.

2) Firebricks for industrial use remain in Kitakyushu district as industrial heritage.

3) Results of field survey on the firebricks for industrial use remain in Kitakyushu district and significance on the history of technology.
\end{abstract}

Key Words : Firebrick, Stamp, TOBATA, BIZEN-INBE, Standard, JES, JIS, Industrial heritage

\section{1. はじめに}

北九州地域においては古くから製鉄や窵業などの産業が発達し， わが国の近代化を牽引してきた. これらの産業においては, 高温と なる各種炉内環境に適応する工業材料である耐火煉瓦が必要であ る.この耐火棟瓦の需要をまかなったのはどこの製造所であったの だろらか. 先ず, 北九州における耐火煉瓦工場について述べ, 続い て北九州で使用された耐火煉瓦の刻印や寸法をもとに, 製造会社や 製造時期を推定し，近代産業の足跡をたどる.

\section{2. 北九州における而火娻瓦工場の創業}

Table 1 は北九州において創業した耐火煉瓦工場を示したもので ある1),2.

1897 (明治 30）年に八幡に製鐵所（通称官営八幡製鐵所）が開 所し，高炉や平炉などの建設にあたっては輸入品が使用された 2. この時，国産品も併用2されているが，後になって輸入に頼らぬよ う耐火棟瓦工場を建設して自給体制をとることとなった ${ }^{3}$.ここ工 場は 1956 (昭和 31) 年, 企業提携により黑崎窟業へ移管されてい $ろ^{2}$.

九州耐火煉瓦は西部合同瓦斯や東邦電力などの社長を務めた松 永安左エ門(1875-1971)によって，拡大する需要に応えるため設立 されている3).

1917 (大正 6) 年の「北九州工業の旺盛」と題する新聞記事 1) には，製鉄，セメント，硝子などの工場に混じって九州耐火煉瓦， 戸烟耐火㶱瓦製造所，日本而火煉瓦が紹介されており，北九州の工 業での必要性と業界の繁栄をうかがうことができる．その反面， 大規模な需要がある製鉄や硝子の工場は自給体制をとつたため, 而 火棟瓦専業の会社には厳しい情勢であったといわれる2。

Table 1 Foundations of firebrick manufacturer in Kitakyushu district

\begin{tabular}{|c|c|c|}
\hline 年次 & 社名 & 場所 \\
\hline 1897 (明治 30) & 日本耐火棟瓦株 & 戸畑 \\
\hline 1903 (明治 36） & 戸畑耐火棟瓦製造所(資) & 戸畑 \\
\hline 1903 (明治 36) & 若松耐火棟瓦製造所 & 戸畑 \\
\hline 1904（明治 37） & 製鐵所酎火棟瓦工場 & 八幡 \\
\hline 1916 (大正 5) & 九州耐火棟瓦株 & 枝光 \\
\hline 1917 (大正 6) & 帝国特殊耐火棟瓦(㑣) & 小倉 \\
\hline 1917 (大正 6) & 福岡㕓業株 & 門司 \\
\hline 1918（大正 7) & 黒崎窯業林 & 黑崎 \\
\hline 1935 (昭和 10) & 和気耐火工業株 & 門司 \\
\hline
\end{tabular}

\section{3. 北九州で使用された耐火棟瓦}

北九州工業の旺盛を支えた耐火棟瓦は，前述の工場による生産で まかなわれたのであろうか. 北九州の戸畑, 八幡, 若松でみられた 而火棟瓦について調べ，製造会社や製造時期を推定する.

3.1 戸畑地区

Fig.1 は，炭鉱をはじめ，安川電機，黒崎窯業などの経営 4で知 られる松本健次郎の旧邸である. 辰野片岡建築事務所の設計で 1912 (明治 45）年に戸烟に建設され，後に重要文化財となった4).

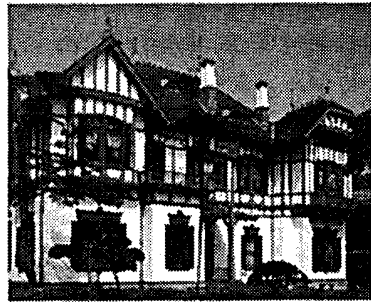

Fig.1 MATSUMOTO Kenjiro residence

Fig.2 は，この建物の暖炬に使用されている耐火煉瓦であり，肌 色で TOBATA の文字と井桁に H の刻印が認められる. これは前 述の戸畑耐火煉瓦製造所のものと推察される。

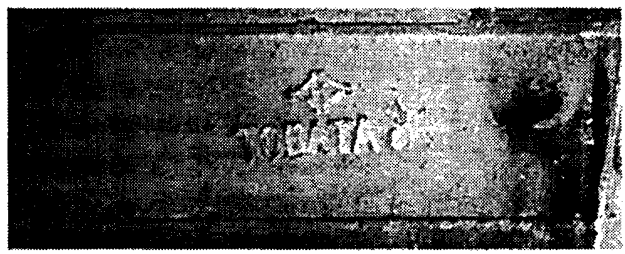

\section{2 八幡地区}

Fig.2 Firebrick of Tbbatataikarenga in fireplace

以下に,八幡においてみられた耐火棟瓦について報告する. Fig.3 は東田第一高炉史跡広場であり，1962（昭和 37）年建設の高炉 4) をはじめ，トーピードカーや転炉などが保存されている. 製鐵所創 業当初の高炉や平炉は，既に解体されている。

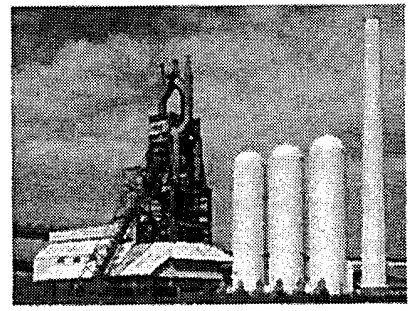

Fig.3 Historic site of the Imperial Japanese Government Steelworks

No. 08-57 技術と社会の関連を巡って：過去から未来を訪ねる〔2008-9. 20，小倉〕 
この史跡広場の熱風炉下の煙道にある耐火棟瓦には, Fig.4 と同 様の六角形中に Y の文字が入った刻印をみることができる.これ は現在の黑崎播磨の前身である黒崎窯業2を示している.

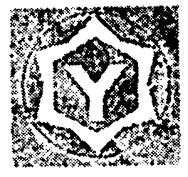

Fig.4 Stamp of Kurosakiyogyo

また，八幡にお゙いて Fig.5 に示す BIZEN-INBE の刻印がある白 色の耐火棟瓦が確認できた。 この刻印は, 備前陶器伊部工場で作ら れたことを示す 5)。この会社は備前焼で知られる岡山県の伊部で 1896 (明治 29）年に設立され，1909（明治 42）年に日本窯業と なり 1916 (大正 5) 年に品川白棟瓦に吸収合併された ${ }^{6}$ ). 明治から 大正時代にかけて製造されたものと思われる. なお，以降に示す拓 本は $1 / 4$ に縮小して示している.

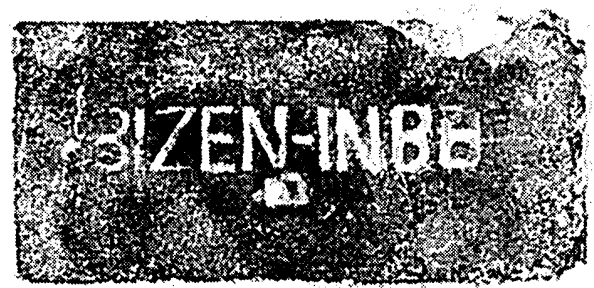

Fig.5 Firebrick of Bizentoki

Fig.6 は，H.S.FI と MITS の刻印がみられる白色の耐火煉瓦の 破片である. 群馬県館林市にあった上毛モスリンの解体時の調查に おいて, H.S.FIREBRIC MITSUISHI の刻印があり，岡山県の三 石耐火煉瓦のものと推定される耐火煉瓦の存在が認められた 7). Fig.6 の破片も同様のものと推察される.

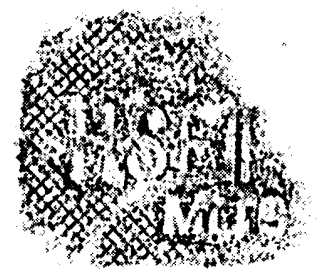

Fig.6 Firebrick of Mitsuishitaikarenga

Fig.7 の耐火棟瓦は，肌色で Fig.2 と同様の刻印が認められ，戸 畑耐火煉瓦製造所のものと思われる. 厚さが $88(\mathrm{~mm})$ ある異形棟瓦 で，現在の ЛS 規格にはない寸法である ${ }^{8)}$.

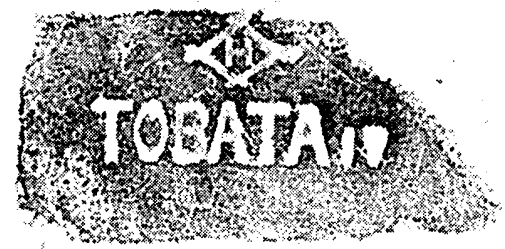

Fig.7 Firebrick of Tobatataikarenga

他に, Fig.8 の品川白煉瓦の社章である菱形に SS の文字が入つ たものや，東洋耐火と思われる ToyoF まで読み取れるもの，意味 不明の印に RA16 とあるものなどが認められた. しかし, 輸入耐火 棟瓦の実物は確認できず, 北九州で最大の生産量を誇った製鐵所の 耐火棟瓦工場 8)を示す刻印は不明であった。

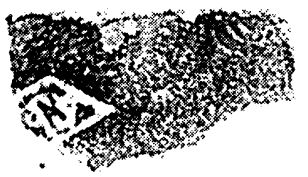

Fig.8 Firebrick of Shinagawashirorenga
Table 2 は耐火煉瓦の規格種類と寸法を示したものである ${ }^{8)}$. 広 く用いられる並型の耐火棟瓦の寸法について, 大正時代に日本標準 規格である JES が制定される際の調査では，東京型が多いものの， 海軍では英国型，ガス会社では 3 时 英国型が用いられ，一様でな いことが報告されている ${ }^{8}$. Fig.5 の寸法は下記のいずれの規格に も当てはまらず，Fig.6については東京型と思われることから，双 方とも大正期の規格制定以前や，規格が普及しない時期に製造され たと考えられる.

Table 2 Standards and size of firebricks

\begin{tabular}{|l|l|l|}
\hline \multicolumn{1}{|c|}{ 名称 } & 長さ $\times$ 幅 $\times$ 厚さ $(\mathrm{mm})$ & \multicolumn{1}{c|}{ 備考 } \\
\hline 東京型 & $227 \times 109 \times 61$ & $7.5 \times 3.6 \times 2$ (寸) \\
\hline 英国型 & $229 \times 114 \times 64$ & $9 \times 4.5 \times 2.5$ (吋) \\
\hline 3 时 英国型 & $229 \times 114 \times 76$ & $9 \times 4.5 \times 3$ (吋) \\
\hline JES 並型標準 & $215 \times 115 \times 65$ & 1925 年 (大正 14) \\
\hline JES 並型標隻改正 & $230 \times 114 \times 65$ & 1942 年 (昭和 17) \\
\hline JS 並型標準 & $230 \times 114 \times 65$ & \\
\hline 備前陶器(Fig.5) & $235 \times 110 \times 63$ & \\
\hline 三石耐火棟瓦(Fig.6) & (破損) $\times 110 \times 62$ & \\
\hline
\end{tabular}

\section{3 若松地区}

日本板硝子若松工場は，日本板硝子に改称される以前の日米板硝 子が 1918 (大正 7) 年に二島工場として設立している. 工場跡は, 再開発により大型ショッピングセンターとなっており, 工場の沿革 の説明板と使用された耐火棟瓦のモニュメントが設置されている. 同工場跡からほど近く，板硝子製造で用いられた耐火棟瓦を再利用 して築かれた擁壁がある. Fig.9 (180 回転) はその一部で, BATA の文字と，丸の中に T と A と B を組み合せた印が入っている. 他 の断片とあわせると TOBATA という刻印であったことがわかる. 戸畑耐火棟瓦の製品と思われるが, 戸畑と八幡でみられた井桁に $\mathrm{H}$ の印と異なる. ここでは他に, 品川白棟瓦の社章である菱形に SS の文字が入ったものや, 製造所不明の印があるものなどが認められ た.

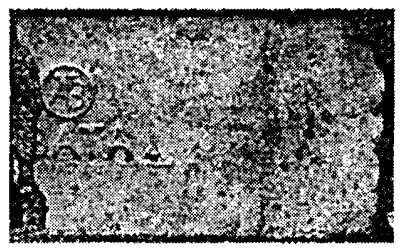

Fig.9 Firebrick of Tobatataikarenga in brickwall

4. おわりに

北九州において製鉄や窝業などの産業の発展とともに, 使用され る而火煉瓦が同じ地域で生産が進められたことを, 文献と現物とで 確認できた. また, 豊富な需要をまかなうため, 北九州以外の会社 で製造されたものも使用されたことが認められた. 刻印や寸法から， 製造時期が明治から大正と推定されるものがあり，古くから国産の 而火煉瓦の流通が全国的に進んでいたことがうかがえた。

\section{参考文献}

1）北九州市産業史編集委員会：北九州市産業史,北九州市, (1998),p.286.

2）黑崎空業式会社社史編集委員会：黑崎空業五十年史,黑崎突業物会 社, (1969),pp.3-14.

3）九州耐火棟瓦株式会社：創業七十年史,九州耐火棟瓦株式会 社,(1987),pp.2-4

4) 北九州地域史研究会 : 北九州の近代化遺産弦書房, (2006),pp.157-159.

5）大阪歴史博物館：特別展 煉瓦のまち タイルのまち一近代建築と都市 の風景一,大阪歷史博物館, (2006),p.43.

6）備前市歴史民俗資料館：備前市の耐火物,備前市歴史民俗資料 館,(2005),pp.11-13.

7）館林市教育委員会文化振興課：旧上毛モスリン㑣関車近代化遺産調查 報告書,館林市教育委員会文化振興課，(1997),p.46.

8）竹内清和：耐火煉瓦の歷史一セラミックス史の一断面一,内田老鶴 囷,(1999),pp.96-98. 